Jorune Jazdauskaite,

Klaipeda University, Lithuania

email:jorune.jazdauskaite@ku.It

Magdalena Prívarova,

Professor, University of Economics in Bratislava, Slovak Republic

(iD) ORCID ID, 0000-0003-2884-9690

email: magdalena.privarova@euba.sk

Edita Baranskaite,

Dr.Sc., Klaipeda University, Lithuania

email: edita.baranskaite@ku.lt

Vytautas Juscius,

Dr.Sc., Professor, Klaipeda University, Lithuania

email: ek.shmf@ku.lt

Nikoletta Kelemen-Henyel,

Hungarian University of Agriculture and Life Sciences, Hungary

email: henyel@henyel-kelemen.de

Correspondence author: edita.baranskaite@ku.lt

\title{
EVALUATION OF THE IMPACT OF SCIENCE AND TECHNOLOGY ON THE LABOUR MARKET
}

Abstract. Science and technology have led to economic growth for more than 250 years. Three industrial revolutions were observed during this period. New technologies are still rapidly developed every day. Robots, various algorithms, 3D printing, artificial intelligence, software help people perform various tasks. The dissemination of information is digitized. Science and technology are seen as a tool of economic progress. Science and technology are composed of research and experimental development, social innovation research, high technology, and human resources in science and technology. Each of these components is linked to economic impact. One of the affected areas is the labor market. The labor market as a macroeconomic factor is described through employment and unemployment. Science and technology affect it, but the direction of impact is widely questioned. On the one hand, disseminating and implementing science and technology requires constant updating of knowledge. It could lead to widespread technological unemployment, as many people may lose their jobs due to automated jobs. On the other hand, the latest technologies could also lead to new businesses or new sectors and new jobs or professions. With the implementation of scientific technologies, the nature of work is changing. There is a need for specialists with higher qualifications, new knowledge. Such discussion reveals the lack of research that evaluates the impact of science and technology on the labor market. For revealing the impact of science and technology on the labor market, the analysis of Lithuanian statistical data and economic indicators was performed in the data collection process. The study involved correlation and regression analyses to evaluate the results. Correlation and regression analyses revealed that science and technology positively affect the growth of the country's employment rate and monthly wages (gross) and the decrease in the unemployment rate.

Keywords: science, technology, economic, impact, labor market.

Introduction. Science and technology have led to economic growth for more than 250 years. Thus, robots, various algorithms, 3D printing, artificial intelligence, software help people perform various tasks. Dissemination of information moves to the Internet, electronic press, mobile phones (Gedviliene and Kankeviciene, 2014). Science and technology are seen as a tool of economic progress. This progress is mostly reflected in the labor market as it could lead to the risk of large-scale technological unemployment

Cite as: Jazdauskaite, J., Privarova, M., Baranskaite, E., Juscius, V., \& Kelemen-Henyel, N. (2021). Evaluation of the Impact of Science and Technology on the Labour Market. Marketing and Management of Innovations, 4, 153-167. http://doi.org/10.21272/mmi.2021.4-12 
J., Jazdauskaite, M., Privarova, E., Baranskaite, V., Juscius, N., Kelemen-Henyel. Evaluation of the Impact of Science and Technology on the Labour Market

and significantly impact the labor market (Chinoracky and Corojeva, 2019). Advances in science and technology could affect the labor market, as some workers without certain qualifications may lose their jobs due to the automation of their workplace (Afonso, 2016). However, other researchers disagree with this view. They argue that science and technology do not affect unemployment because technological change reduces labor demand and the cost and price of products and services, increasing production demand (Upadhyay, 2015). According to Chiacchio, Patropolos, and Pichler (2018), science and technology create innovations that lead to new professions in the market and demand workers with knowledge in new areas. Science and technology are especially relevant for entrepreneurs, the country's economy, and scientists. Still, there is a lack of more detailed research on the impact of science and technology on the labor market.

Literature Review. Science and technology, as separate units, are very similar. However, they could be perceived very differently. The relationship between science and technology is very complex. Therefore, it is important to analyze science as a source of technology and technology as a source of science. It could be approached as science as a source of technology (Bernhard, 2017; De Groen and Maselli, 2016; Martinez, 2018) or technology as a source of science (Martinez, 2018; West, 2015; Rechnitzer et al., 2019; Zhang, Wang and Liu, 2020; Raisiene et al., 2021). According to Eurostat, science and technology comprise research and experimental development, social innovation research, high technology, and human resources in science and technology.

Research and experimental development (R\&D) is one of the main factors promoting the development and competitiveness of the country's economy. The economic growth in a country is driven by spending on R\&D activities. Countries that prioritize R\&D activities create higher added value and factor productivity as production is shifted to producing new services and products with a higher value for consumers (Afonso, 2016). According to Federaviciute (2008), the growth of factor productivity is also stimulated by innovations that reduce production costs. With the same amount of labor and capital in a company, greater benefits could be achieved. In recent years, public innovation research has been recognized as a key tool for improving organizational efficiency and performance. In addition, the importance of social innovation research in organizations has grown significantly due to factors such as increasing globalization, the acceleration of technological change, or the need to share the best results (Donate and Guadamillas, 2011). The key role of social innovation research in fostering innovation in today's business environment is creating, strengthening, and sustaining competitive advantage through knowledge and collaboration.

High technologies are oriented towards creating higher value and guaranteeing the increase of society's economic well-being, providing an opportunity to solve various problems related to culture, science, technological and security progress (Micic, 2017; Karacsony et al., 2021). Increasing attention has to be paid to high technology to enable as many people as possible to work in innovation-related jobs, as well as to increase productivity and economic activity in all areas of activity in the context of added value and social attractiveness (Kvedariene and Svediene, 2016; Karacsony et al., 2020).

Analyzing the state of technology, Supa (2018) stated that increasing investment in innovations that affect certain activities, the need to expand the number of experimental research, the need for international cooperation, the role of highly qualified workers in the market, and investment in investment human capital and competence. All these factors influence developing the knowledge economy nationally and internationally. Labor market as a macroeconomic factor. The labor market could be described through employment and unemployment. According to Pocius and Neverauskiene (2015), employment is a macroeconomic factor that expresses the relationship between working-age people and the unemployed in a region. Employment plays an essential role in the country's labor market. As a base for social stability, it ensures using social protection tools development in employment relations (Bilan et al., 2019; Mishchuk et al., 2020). 
J., Jazdauskaite, M., Privarova, E., Baranskaite, V., Juscius, N., Kelemen-Henyel. Evaluation of the Impact of Science and Technology on the Labour Market

Unemployment is described as an imbalance between supply and demand. It is one of the main factors causing problems in the country's labor market (Cangia, 2019; Gervyte, 2008). When analyzing unemployment, it is essential to find out the causes of unemployment (Table 1)

Table 1. Causes of unemployment

\begin{tabular}{ll}
\hline Causes of unemployment & \multicolumn{1}{c}{ Factors } \\
\hline Country tax policy & $\begin{array}{l}\text { With high taxes, companies have fewer opportunities to expand and develop their } \\
\text { operations, which encourages the growth of the shadow economy. }\end{array}$ \\
$\begin{array}{l}\text { Scientific and technological } \\
\text { progress }\end{array}$ & $\begin{array}{l}\text { With the introduction of technology, there is a need for higher-skilled workers, so part } \\
\text { of the unskilled workforce becomes unemployed. } \\
\text { Wage regulation }\end{array}$ \\
$\begin{array}{l}\text { The introduction of a minimum wage raises wages. It reduces the demand for } \\
\text { unskilled labor. Therefore, companies could no longer hire workers with low added } \\
\text { value. }\end{array}$ \\
$\begin{array}{ll}\text { Growing competition in world The globalization of economic activity and increasing global competition encourage } \\
\text { markets }\end{array}$ \\
$\begin{array}{l}\text { companies to reduce production costs and productivity and introduce new } \\
\text { technologies. It creates preconditions for reducing the amount of labor. }\end{array}$ \\
unemployment benefits & $\begin{array}{l}\text { High levels of unemployment benefits encourage people not to work and live solely } \\
\text { on the benefits they receive. The higher the incapacity benefits in a country, the more }\end{array}$ \\
Inflation & $\begin{array}{l}\text { long-term unemployment is. } \\
\text { Efforts are being made to reduce inflation by raising taxes, cutting government } \\
\text { spending, and limiting the money supply. These measures reduce the production } \\
\text { volume of enterprises, which leads to an increase in unemployment in the country. } \\
\text { During economic crises, production declines, and unemployment rises. With the } \\
\text { economy booming, rising GDP indirectly increases employment and reduces } \\
\text { unemployment. }\end{array}$ \\
\hline
\end{tabular}

Sources: developed by the authors based on (Paliunaite, 2011; Gulbiniene et al., 2011, Tamoseviciene and Staroselskaja, 2018).

High unemployment is caused by more than one cause. It makes it difficult to estimate the real national unemployment rate because the shadow economy does not always show the true unemployment rate. However, it can be argued that all the causes of unemployment are important to the economy of any country that seeks to increase employment.

There may be different consequences:

- Unemployment in the narrow sense affects a person. A person who has lost his/her job loses a source of income, and incapacity benefits only partially compensate for the loss of income. It results in a deterioration in a person's standard of living and loss of work experience.

- In a broad sense, unemployment affects the entire economy of a country. When the economy becomes unable to create enough jobs as many people are willing and able to work, and employment falls below a certain level, the country loses part of its national product, which remains unproduced. Losses arise from non-produced goods and services and the payment of incapacity benefits (Simanaviciene and Uzkuryte, 2009; Dudu, 2021).

- Labor emigration may change the workforce's qualification structure due to a shortage of skilled workers and a surplus of unskilled workers (Gataliunas, 2015; Bite et al., 2020; Prívara et al., 2020).

After analyzing the scientific literature, it could be noticed that unemployment also appears in the labor market in addition to employment. It is described as an imbalance between labor supply and demand. The following causes of unemployment are distinguished: tax policy, scientific and technological progress, wage regulation, growing competition in world markets, conditions for receiving unemployment benefits, inflation, economic crises. The consequences of unemployment affect both the individual and the country's economy. Therefore, to reduce unemployment in the country, it is necessary to increase employment. 
J., Jazdauskaite, M., Privarova, E., Baranskaite, V., Juscius, N., Kelemen-Henyel. Evaluation of the Impact of Science and Technology on the Labour Market

Methodology and research methods. In data collection, statistical data and economic indicators are analyzed. Data ranking is used to process the collected data, and correlation and regression analyses are performed to evaluate the results.

The main research method is correlation and regression analysis. Therefore, the theoretical assumptions of the values required for the analysis are presented below. The correlation coefficient (R) and its numerical expression vary from -1 to 1 . This coefficient shows the bond strength and direction of the studied variables (Table 2). Empirical research on the application of gamification was conducted to evaluate the impact of gamification on increasing employee engagement. A quantitative research method was selected to assess the effect of gamification on different participants' engagement and determine the strength of this effect. Depending on the set criteria, an organization was selected for testing, which uses several game components in the internal staff IT system: leader board, score collection for different tasks, badges, levels.

Table 2. Correlation strength

\begin{tabular}{llllll}
\hline Correlation coefficient & $0-0,19$ & $0,2-0,39$ & $0,4-0,69$ & $0,7-0,89$ & $0,9-1$ \\
\hline Link strength characteristic & Very weak & Weak & Mean & Strong & Very strong \\
& $\begin{array}{l}\text { correlation (no } \\
\text { relation) }\end{array}$ & $\begin{array}{l}\text { correlation } \\
\text { (weak relation) }\end{array}$ & $\begin{array}{l}\text { correlation } \\
\text { (mean relation) }\end{array}$ & $\begin{array}{l}\text { correlation } \\
\text { (strong relation) }\end{array}$ & correlation \\
& & & & \\
\hline
\end{tabular}

Sources: developed by the authors based on (Bekesiene, 2015).

The strength of the correlation relationship shows how one variable depends on another variable. The direction of the relationship of the variables could be positive. This value reveals a direct dependence of the variables when the values of both variables change in one direction. The negative value indicates that the values of one variable increase and the values of the other decrease (Bekesiene, 2015).

Regression analysis was performed after calculating the correlation coefficient and establishing a relationship between the variables has been established. Regression analysis makes it possible to determine the influence of factors on the variable in question, which mathematically means the dependence of the dependent variable $y$ on the independent variable $\mathrm{x}$. Cekanavicius and Murauskas (2014) distinguished the requirements for the validity of regression analysis:

- The coefficient of determination (R2) is the most important characteristic of the reliability of a linear regression analysis model. The coefficient of determination takes values from the range $0 \leq R 2 \leq 1$. The higher the value of the coefficient, the better the model. Bad when $\mathrm{R} 2<0,25$.

- ANOVA $p$ the value indicates whether the model has regressors associated with the dependent variable. If $p>0,05$, the suitability of the regression model is questionable, and when $p<0,05$, such a model is not hopeless.

The authors (Cekanavicius and Murauskas, 2014) distinguished the main principles of regression analysis data as follows: the dependent variable y must correlate with the regressors. The closer regressors are to the normal random variables, the better they fit the model; all variables must be based on intervals; there should be no exceptions in the data.

It could be deduced from the regression coefficient that the value of one characteristic would change by several units, while the value of another characteristic would change by one unit.

Research data processing. For revealing the relationships between the study variables, empirical data was obtained based on statistical data sources Eurostat and Statistics Lithuania. A statistical database is created in Microsoft Excel. Then, data is transferred to SPSS (Statistical Package for Social Sciences) program to perform correlation and regression analyses. The analyzed data is transferred to Microsoft Word. The main labor market indicators were selected to analyze the impact of science and technology on the Lithuanian labor market: employment, unemployment, and average wages (gross). The study uses 
J., Jazdauskaite, M., Privarova, E., Baranskaite, V., Juscius, N., Kelemen-Henyel. Evaluation of the Impact of Science and Technology on the Labour Market

the main science and technology variables: employment in high-tech sectors, persons with higher education and/or working in science and technology, the number of employees involved in R\&D activities, and expenditure on R\&D activities.

Research hypotheses:

- H1: Science and technology indicators positively affect the country's employment growth.

- H2: Science and technology are some factors reducing the country's unemployment rate.

- H3: Science and technology indicators positively affect monthly earnings (gross).

Research period. To make the research results as accurate and up to date as possible, ten years from 2010 to 2019 were chosen.

Results. Science and technology impact on employment. A correlation analysis is performed to assess the impact of science and technology on the employment rate in Lithuania. It shows the strength of the relationship between the independent and the dependent variable and the confidence interval. In this case, the independent variable is science and technology indicators. The dependent variable is the employment rate.

Table 3. Correlation coefficients and confidence intervals for independent variables and employment rates

\begin{tabular}{llll}
\hline \multicolumn{1}{c}{ Independent variable } & \multicolumn{1}{c}{$\begin{array}{c}\text { Pearson correlation } \\
\text { coefficient }\end{array}$} & $\begin{array}{c}\text { Correlation } \\
\text { strength }\end{array}$ & $\begin{array}{c}\text { Confidence } \\
\text { interval }\end{array}$ \\
\hline Employment in high-tech sectors & 0,873 & Strong & 0,001 \\
Higher education and/or science and technology & 0,962 & Very strong & 0,000 \\
professionals & & & \\
Employees involved in R\&D activities & 0,762 & Strong & 0,010 \\
Expenditure on R\&D activities & 0,900 & Very strong & 0,000 \\
\hline
\end{tabular}

Sources: developed by the authors.

Based on the Pearson correlation coefficient results (Table 3), it could be stated that the correlation coefficients of all variables are positive. Thus, there is a direct dependence of the variables - the values of science and technology and employment rates change in one direction. Employment in the high-tech sectors and workers involved in R\&D have a strong correlation with the employment rate. In contrast, those with higher education and expenditure on R\&D have a very strong correlation with the employment rate. Based on the confidence interval, since the values of all variables are less than 0.05 , they are statistically significant. After performing the correlation analysis, it is important to determine whether the data are distributed according to the normal distribution. Therefore, Kolmogorov-Smirnov and ShapiroWilk tests were performed (Table 4).

Table 4. Kolmogorov-Smirnov and Shapiro-Wilk tests for employment rate and independent variables

\begin{tabular}{lll}
\hline \multicolumn{1}{c}{ Variables } & \multicolumn{1}{c}{$\begin{array}{c}\text { Kolmogorov } \text { - Smirnov test } \mathbf{p} \\
\text { value }\end{array}$} & Shapiro - Wilk test $\mathbf{p}$-value \\
\hline Employment rate & 0,200 & 0,748 \\
Employment in high-tech sectors & 0,200 & 0,347 \\
Higher education and/or science and & 0,200 & 0,319 \\
technology professionals & & \\
Employees involved in R\&D activities & 0,200 & 0,133 \\
Expenditure on R\&D activities & 0,200 & 0,996 \\
\hline
\end{tabular}

Sources: developed by the authors. 
J., Jazdauskaite, M., Privarova, E., Baranskaite, V., Juscius, N., Kelemen-Henyel. Evaluation of the Impact of Science and Technology on the Labour Market

Based on the data in Table 4, it could be stated that the total p-values of both tests are greater than 0.05 . Therefore, all distributions are close to normal. After performing correlation analysis and normality test, the linear regression analysis model is evaluated, and regression equations are formed. Assessing the relationship between science and technology indicators and employment rate according to ANOVA pvalues, all linear regression models have regressors related to the dependent variable y because all $p$ values are less than 0.05 . Figures $1-4$ show the regression analysis results of the independent and dependent (the employment rate) variables.

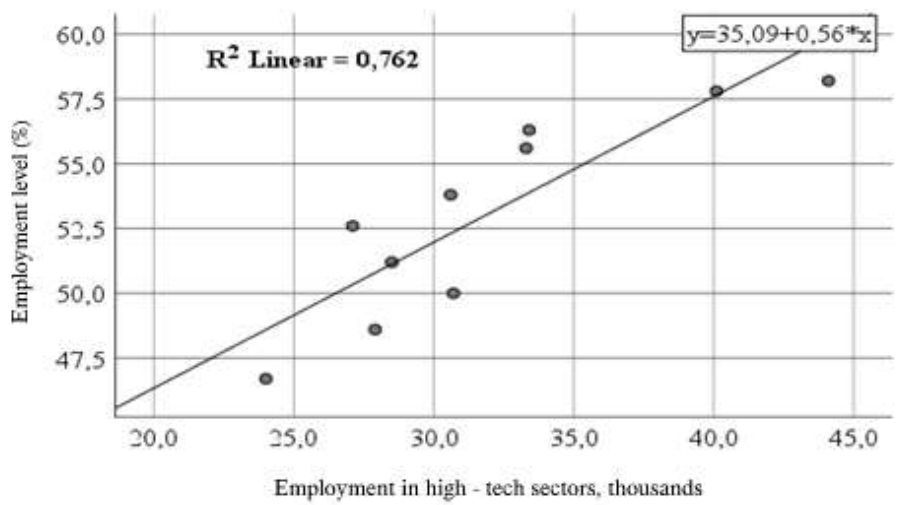

Figure 1. Graph of linear regression of employment in high-tech sectors and employment levels

Sources: developed by the authors.

Based on the employment in the high-tech sectors and the employment rate determination coefficient (0.762) (Figure 1), it could be stated that the calculated value is appropriate because it is higher than 0.25 . This value shows that changes in employment levels explain 76.2 percent of changes in employment in high-tech sectors. The equation of linear regression analysis helps to define more precisely how the employment rate would change as employment changes in high-tech sectors. Figure 2 shows that the coefficient of determination is equal to 0.926 . Thus, it indicates that the independent variable explains 92.6 percent of the dependent variable.

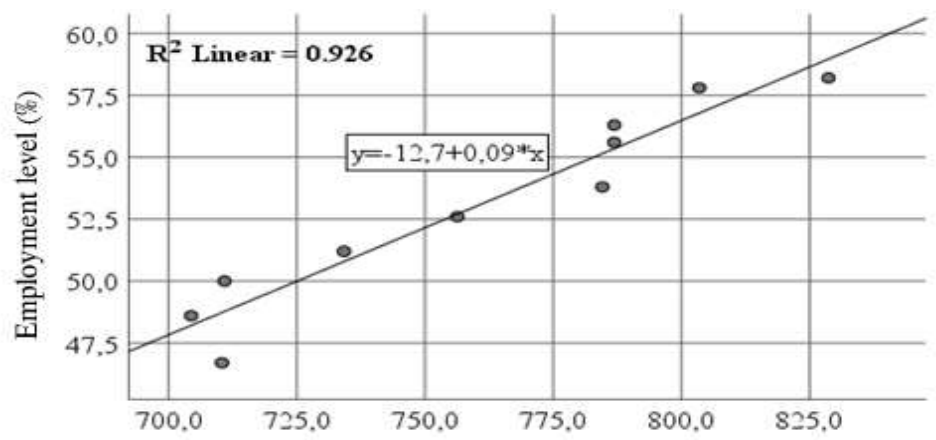

Persons with higher education and/or working in science and technology, thousands

Figure 2. Graph of linear regression of persons with higher education and/or working in science and technology and employment level

Sources: developed by the authors. 
J., Jazdauskaite, M., Privarova, E., Baranskaite, V., Juscius, N., Kelemen-Henyel. Evaluation of the Impact of Science and Technology on the Labour Market

The relationship between persons with higher education and/or working in science and technology and the employment rate is described by a linear function (Figure 2). Therefore, if the number of persons with higher education and/or working in science and technology increased by 1,000 , the employment rate would increase by 0.09 percent.

Based on Figure 3, the number of employees participating in R\&D activities and the employment rate determination coefficient presented in 2006, the number of employees participating in R\&D activities explains 58 percent dissemination of employment rates.

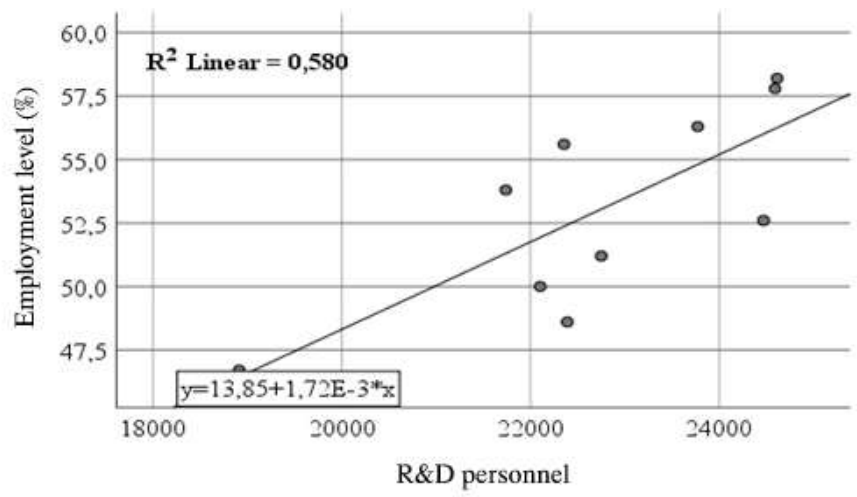

Figure 3. Graph of linear regression of employees involved in R\&D activities and employment

Sources: developed by the authors. levels

Figure 3 shows that the points are far from the line. However, this scattering is significant, as there is a strong relationship between R\&D personnel and the employment rate. Only a larger unexplained proportion emerges, suggesting that other factors not included in the analysis influenced the employment rate. Figure 3 shows that if the number of employees involved in R\&D activities increased by 1 employee, the employment rate would increase by 0.002 percent.

Analyzing the linear regression graph of expenditure on R\&D activities and employment level (Fig. 4), the coefficient of determination R2 is 0.810 . Therefore, this model is suitable because R2 $>0.25$. The coefficient of determination shows that the change in expenditure on R\&D activities an 81 percent explains the change in the employment rate.

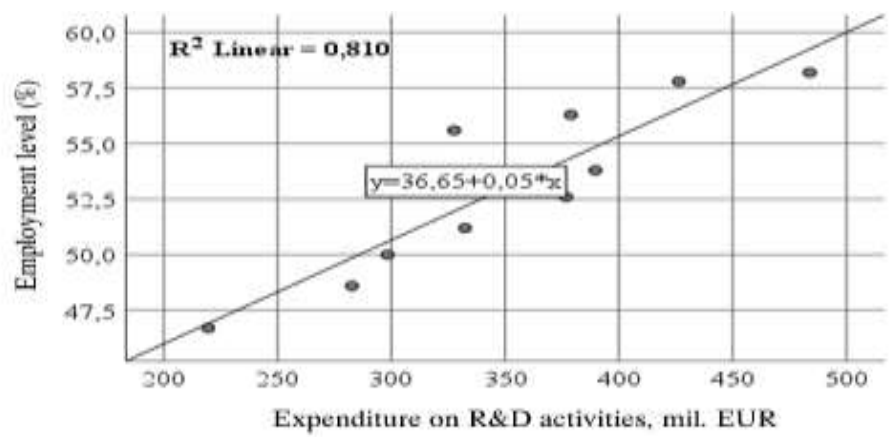

Figure 4. Graph of linear regression of R\&D expenditure and employment rate Sources: developed by the authors. 
J., Jazdauskaite, M., Privarova, E., Baranskaite, V., Juscius, N., Kelemen-Henyel. Evaluation of the Impact of Science and Technology on the Labour Market

The results of the linear regression analysis (Figure 4) show that if the independent variable (expenditure on R\&D activities) increased by 1 million, the average estimated size of the dependent variable (the employment rate) would increase by 0.05 percent.

Summarizing the correlation and regression analysis results of the impact of science and technology on the employment rate in Lithuania, all the analyzed science and technology indicators have a strong or very strong correlation with the employment level. Besides, all analyzed correlations are statistically significant. The values of the analyzed indicators change in one direction. Thus, as science and technology indicators increase, so does the employment rate. It is also important to mention that all the variables examined are distributed according to the normal distribution. Correlation and regression analyses revealed that the first hypothesis was confirmed: science and technology positively affect the growth of the Lithuanian employment rate.

Firstly, a correlation analysis was performed to assess the impact of science and technology on the unemployment rate in Lithuania. Pearson correlation coefficient and confidence interval between the dependent variable (unemployment rate) and independent variables (science and technology indicators) are calculated (Table 5).

Table 5. Correlation coefficients and confidence intervals for independent variables and unemployment rates

\begin{tabular}{lccc}
\hline \multicolumn{1}{c}{ Independent variable } & $\begin{array}{c}\text { Pearson correlation } \\
\text { coefficient }\end{array}$ & $\begin{array}{c}\text { Correlation } \\
\text { strength }\end{array}$ & $\begin{array}{c}\text { Confidence } \\
\text { interval }\end{array}$ \\
\hline Employment in high-tech sectors & $-0,817$ & Strong & 0,004 \\
Higher education and/or science and technology & $-0,940$ & Very strong & 0,000 \\
professionals & $-0,767$ & Strong & 0,010 \\
Employees involved in R\&D activities & $-0,892$ & Strong & 0,001 \\
Expenditure on R\&D activities & &
\end{tabular}

Sources: developed by the authors.

Pearson correlation coefficients of all the analyzed variables in Table 5 are negative, which means that as the values of one variable increase, the values of the other variable decrease. In this case, unemployment in Lithuania decreased during the period under review, and the values of independent variables showed an increasing trend. The unemployment rate strongly correlates with persons with higher education and/or working in science and technology. The remaining indicators of science and technology have a strong correlation. The confidence intervals for all variables examined are less than 0.05 . Therefore it confirms that all variables are statistically significant.

Before performing the regression analysis, it is necessary to determine whether the dependent variable (unemployment rate) corresponds to the normal distribution.

Table 6. Kolmogorov-Smirnov and Shapiro-Wilk tests for the unemployment rate

\begin{tabular}{lcc}
\hline Variables & Kolmogorov-Smirnov test p-value & Shapiro-Wilk test p-value \\
\hline Unemployment rate & 0,200 & 0,414 \\
\hline
\end{tabular}

Sources: developed by the authors.

The results of the Kolmogorov-Smirnov and Shapiro-Wilk tests presented in Table 6 confirmed that the unemployment rate has a normal distribution $(p>0.05)$. Therefore, it is suitable for regression analysis.

After performing correlation analysis and normality test, the linear regression analysis model is evaluated, and regression equations are formed.

Assessing the relationships between science and technology indicators and the unemployment rate according to the ANOVA p-values (Appendices 6-9), it could be stated that all models have regressors 
J., Jazdauskaite, M., Privarova, E., Baranskaite, V., Juscius, N., Kelemen-Henyel. Evaluation of the Impact of Science and Technology on the Labour Market

related to the dependent variable $y$, since all $p<0.05$. Figures 5 - 9 visualize the regression analysis results of the independent variables and the dependent variable (the unemployment rate).

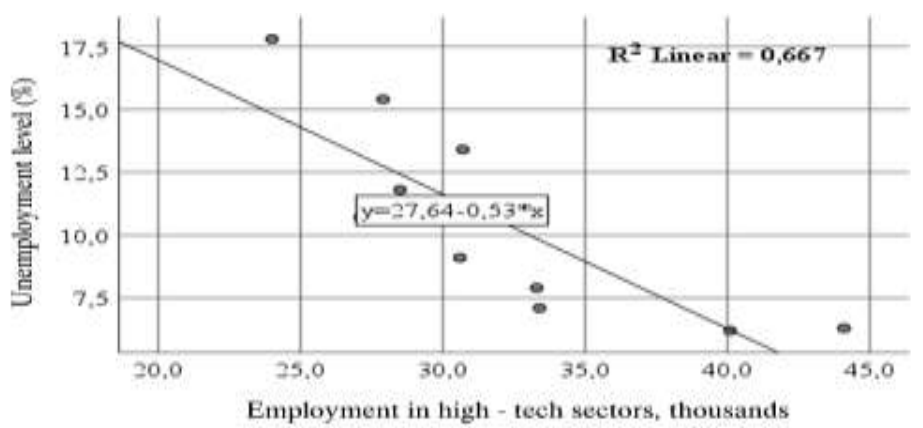

Figure 5. Graph of linear regression of employment in high-tech sectors and unemployment Sources: developed by the authors.

Figure 5 shows that the points are far from the line, but such scattering is significant because there is a strong relationship between employment in high-tech sectors and unemployment. The coefficient of determination allows stating that employment in high-tech sectors explains a 66.7 percent unemployment spread. The linear regression equation (Figure 5) shows that when employment in high-tech sectors increases by 1 thousand, the unemployment rate is set to fall by 0.53 percent.

Analyzing the regression of the number of persons with higher education and/or working in science and technology and the unemployment rate (Figure 6), it is seen that R2 $=0.884$. The coefficient of determination shows that the change in the number of persons with higher education and/or working in science and technology explains 88.4 percent of the change in the unemployment rate.

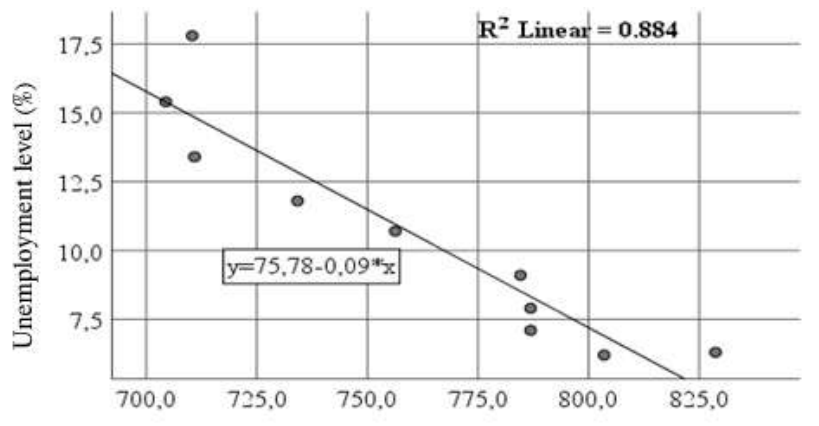

Persons with higher education and/or working in science and technology, thousands

Figure 6. Graph of linear regression of persons with higher education and/or working in science

Sources: developed by the authors. and technology and the unemployment rate

To analyse the changes in the unemployment rate according to the number of persons with higher education and/or working in science and technology, it is necessary to interpret the obtained linear regression equation (Figure 6). Thus, if the number of people with higher education and/or working in science and technology increased by 1,000 , the unemployment rate would decrease by 0.09 percent. 
J., Jazdauskaite, M., Privarova, E., Baranskaite, V., Juscius, N., Kelemen-Henyel. Evaluation of the Impact of Science and Technology on the Labour Market

Assessing the relationship between the employees involved in R\&D activities and the unemployment rate according to the coefficient of determination (Figure 7), it can be stated that the calculated value of $\mathrm{R} 2$ is higher than 0.25 . Thus, it proves that the model is appropriate. The number of employees participating in R\&D activities explains 58.9 percent of the unemployment spread.

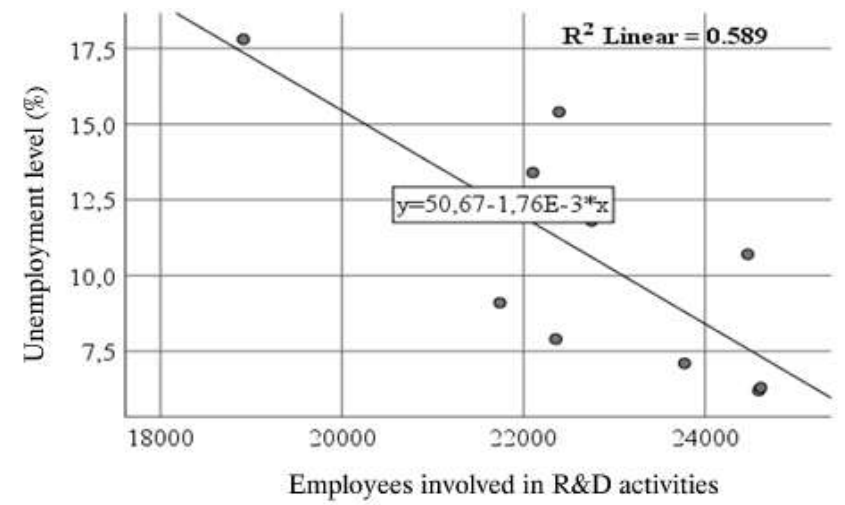

Figure 7. Graph of linear regression of employees involved in R\&D activities and the unemployment rate

Sources: developed by the authors

Figure 7 shows that the points are at a great distance from the straight line. However, this scattering is significant because there is a strong relationship between the workers involved in R\&D activities and the unemployment rate. The increase in the number of employees participating in R\&D activities by one employee decreases by 0.002 percent. Besides, other factors not included in the analysis influence the unemployment rate. Therefore, the smaller part of the variation is explained by the change in the number of employees participating in R\&D activities.

Assessment of the relationship between R\&D expenditure and the unemployment rate under the determination coefficient showed that the calculated value of $\mathrm{R} 2$ is higher than 0.25 . Therefore, the chosen linear regression model is appropriate. The change in the unemployment rate explains a 79.6 percent change in expenditure on R\&D activities (Figure 8).

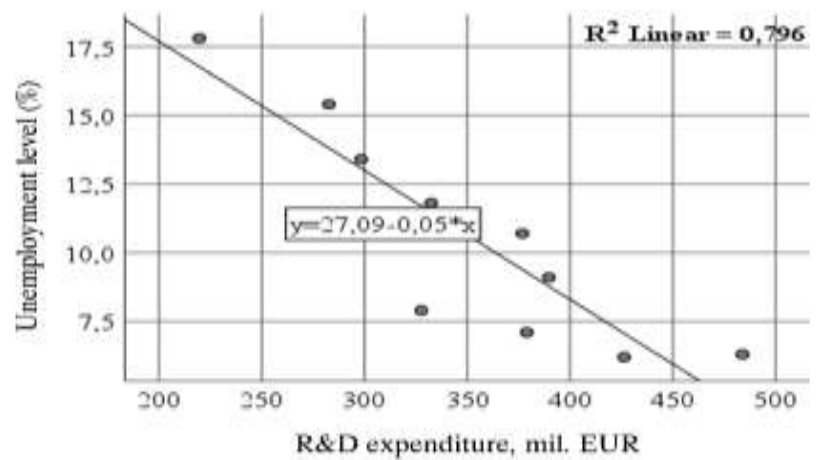

Figure 8. Graph of linear regression of expenditure on R\&D activities and the unemployment rate Sources: developed by the authors. 
J., Jazdauskaite, M., Privarova, E., Baranskaite, V., Juscius, N., Kelemen-Henyel. Evaluation of the Impact of Science and Technology on the Labour Market

The linear regression equation presented in 2006 shows that with the increase in R\&D expenditure by 1 million, the unemployment rate decreased by 0.05 percent (Fig. 8).

The results of the correlation and regression analysis of the impact of science and technology on the Lithuanian unemployment rate showed that all the analyzed science and technology indicators have a strong or very strong correlation with the unemployment rate. Besides, all the analyzed relationships are statistically significant. All the analyzed correlation coefficients are negative. In this case, it means that as the importance of science and technology increases, the unemployment rate decreases. All variables examined are distributed according to the normal distribution. Correlation and regression analyses show that the second hypothesis has been confirmed. Thus, science and technology reduce the unemployment rate in the country.

To find out the influence of science and technology on the monthly salary in Lithuania, a correlation analysis is performed. The strength of the relationship between the variables and the reliability interval are determined. In this case, the dependent variable is monthly earnings (gross), and the independent ones are science and technology indicators (Table 7).

Table 7. Correlation coefficients and confidence intervals for independent variables and monthly earnings (gross)

\begin{tabular}{|c|c|c|c|}
\hline Independent variable & $\begin{array}{l}\text { Pearson correlation } \\
\text { coefficient }\end{array}$ & $\begin{array}{l}\text { Correlation } \\
\text { strength }\end{array}$ & $\begin{array}{c}\text { Confidence } \\
\text { interval }\end{array}$ \\
\hline Employment in high-tech sectors & 0,933 & Very strong & 0,000 \\
\hline $\begin{array}{l}\text { Higher education and/or science and technology } \\
\text { professionals }\end{array}$ & 0,864 & Strong & 0,001 \\
\hline Employees involved in R\&D activities & 0,627 & Average & 0,052 \\
\hline Expenditure on R\&D activities & 0,854 & Strong & 0,002 \\
\hline
\end{tabular}

Sources: developed by the authors.

Pearson correlation coefficients of all variables are positive. It shows a direct dependence of the variables when the values of the variables change in one direction. The Pearson correlation coefficient also reveals a very strong correlation between monthly earnings (gross) and employment in the high-tech sectors. The strong correlation is between monthly earnings (gross) and those with higher education and expenditure on R\&D activities. These variables are statistically significant because their confidence intervals are less than 0.05 . There is an average relationship between monthly earnings (gross) and employees engaged in R\&D activities, and the confidence interval is $p>0.05$. Thus, there is no interdependence between these variables, as the confidence interval is insignificant. Since there is no reliable data between R\&D activities and gross monthly earnings employees, no regression analysis would be performed for this relationship. After the correlation analysis, it is important to determine whether the dependent variable (monthly earnings (gross)) corresponds to the normal distribution. KolmogorovSmirnov and Shapiro-Wilk tests are performed (Table 8).

Table 8. Kolmogorov-Smirnov and Shapiro-Wilk tests for monthly salary (gross)

\begin{tabular}{lll}
\hline Variables & Kolmogorov-Smirnov test $p$-value & Shapiro-Wilk test $p$-value \\
\hline Monthly salary (gross) & 0,200 & 0,019 \\
\hline \multicolumn{2}{l}{ Sources: developed by the authors. }
\end{tabular}

According to Table 8, the Shapiro-Wilk test shows an abnormal distribution of monthly earnings (gross) $(p<0.05)$. However, the result of the Kolmogorov-Smirnov test $(p>0.05)$ stated that it would be used in regression analysis. 
J., Jazdauskaite, M., Privarova, E., Baranskaite, V., Juscius, N., Kelemen-Henyel. Evaluation of the Impact of Science and Technology on the Labour Market

After performing the correlation analysis and the normality test, the evaluation of the linear regression analysis model was further performed, and regression equations were constructed. When considering regression analysis, it is important to note the ANOVA p-value. In this case, the values obtained for the analyzed variables are less than 0.05 . Thus, it could be concluded that the linear regression models are appropriate. The linear regression graphs of the analyzed variables (Figures 9-11).

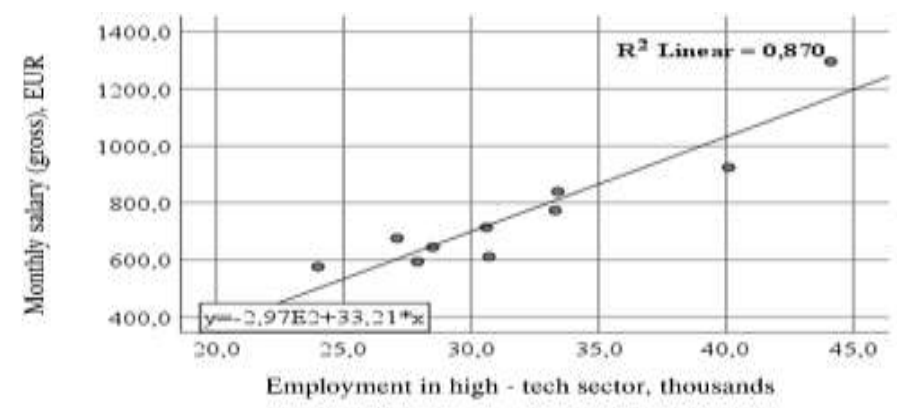

Figure 9. Graph of linear regression of employment in high-tech sectors and monthly earnings

Sources: developed by the authors.

(gross)

After a regression analysis between employment in the high-tech sectors and monthly earnings (gross), the coefficient of determination obtained is equal to 0.870 (Figure 9). The change in employment in high-tech sectors explains an 87 percent change in monthly (gross) earnings. If employment in the hightech sectors increased by 1,000 , the monthly (gross) salary would increase by 33.21 EUR.

After performing a regression analysis of persons with higher education and/or working in science and technology and monthly earnings (gross), the coefficient of determination was 0.747 (Figure 10). Since $\mathrm{R} 2>0,25$, the change in the number of persons with higher education and/or working in science and technology explained an almost 75 percent of the monthly salary (gross) change. By calculating the coefficient of determination of the variables, it was possible to determine how the monthly earnings (gross) would change with an increasing or decreasing number of persons with higher education and/or working in science and technology.

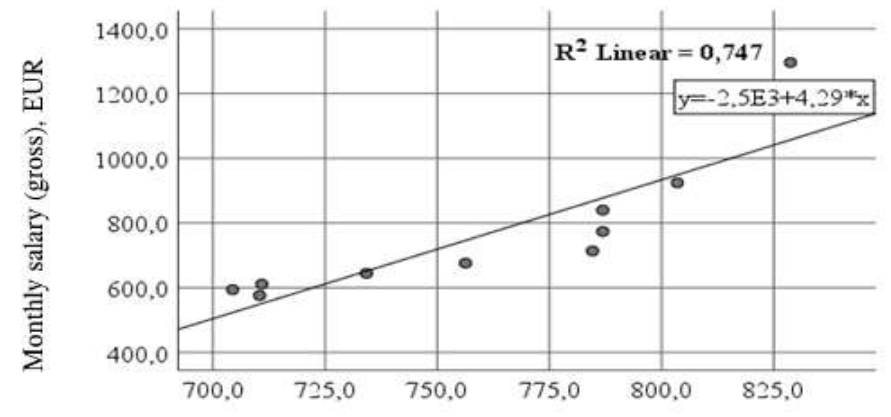

Persons with higher education and/or working in science and technology, thousdands

Figure 10. Graph of linear regression of persons with higher education and/or working in science and technology and monthly earnings (gross)

Sources: developed by the authors. 
J., Jazdauskaite, M., Privarova, E., Baranskaite, V., Juscius, N., Kelemen-Henyel. Evaluation of the Impact of Science and Technology on the Labour Market

Figure 10 shows that if the number of persons with higher education and/or working in science and technology increased by 1,000, the monthly (gross) salary would increase by 4.29 EUR. Analyzing the relationship between expenditure on R\&D activities and monthly wages (gross), the coefficient of determination was 0.729 (Figure 11). The change in expenditure on R\&D activities explains a 73 percent change in monthly wages (gross).

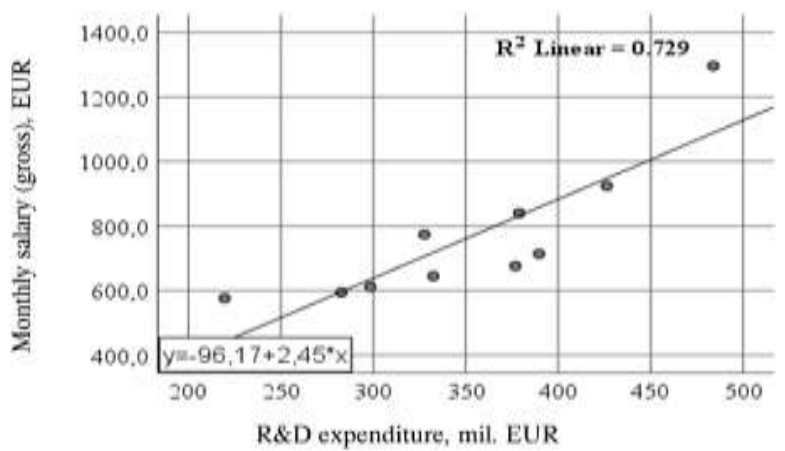

Figure 11. Graph of linear regression of expenditure on R\&D activities and monthly earnings

Sources: developed by the authors.

(gross)

The obtained values of the regression equation parameters helped define more precisely how the monthly wage (gross) would change as the expenditure on R\&D activities changes. In this case, an 1 mil rise in the expenditure on R\&D activities would increase the monthly salary (gross) by 2.45 EUR. The impact of science and technology on monthly wages (gross) in Lithuania showed that employment in hightech sectors, persons with higher education and/or working in science and technology, and expenditure on R\&D activities and dependent variable (monthly labor wage (gross)) have a strong or very strong correlation prevails. These variables are statistically significant. Their values are distributed according to the normal distribution and vary in one direction. The relationship between employees engaged in R\&D activities and monthly wages (gross) is insignificant. The results of regression analysis of variables confirmed the third hypothesis: science and technology indicators have a positive effect on monthly earnings (gross). However, it is important to mention that monthly earnings (gross) depend on many economic and political factors. The regression equations are random and not suitable for wage prediction.

Conclusion. The concept of science and technology consists of 4 components: research and experimental development (R\&D), public innovation research, high technology, and human resources science and technology. The introduction of science and technology in the country is one of the reasons for the country's long-term productivity and economic growth and increasing competition nationally and internationally. Science and technology contribute to employment growth, higher wage growth, job creation, productivity growth, and international mobility. The labor market is a component of the economy. Herewith, human labor is bought or sold in cooperation between the employer, the employee, and the jobseeker. Unemployment is a macroeconomic problem that results in job losses and a deterioration in a person's quality of life. Employment is an economic aspect that reflects the development of a country and the quality of life and well-being of individuals. The level of employment in the country is influenced by microeconomic (human and technical and technological) and macroeconomic (general economic and migratory) factors.

The assessment of the impact of science and technology on the Lithuanian labor market revealed that with a one thousand growth in high-tech sectors employment, the employment rate in Lithuania increased 
J., Jazdauskaite, M., Privarova, E., Baranskaite, V., Juscius, N., Kelemen-Henyel. Evaluation of the Impact of Science and Technology on the Labour Market

by 0.56 percent, the unemployment rate decreased by 0.53 percent, and monthly earnings (gross) increased by 33.21 EUR. As the number of persons with higher education and/or working in science and technology increases by one thousand, the employment rate in Lithuania increased by 0.09 percent, the unemployment rate decreased by 0.53 percent, and the monthly wage (gross) increased by 4.29 EUR. As the number of employees participating in R\&D activities increases by one employee, the employment rate increases and the unemployment rate decreases by 0.002 percent. Employees involved in R\&D activities and monthly earnings (gross) have no statistically significant relationship. Expenditure on R\&D increased by 1 million. In turn, the employment rate increases and the unemployment rate decreased by 0.05 percent, respectively, while the monthly (gross) wage increases by 2.45 EUR. The correlation and regression analysis results confirmed all hypotheses: science and technology positively affect the growth of the country's employment rate, the decrease in the unemployment rate, and the growth of monthly wages (gross).

Author Contributions: conceptualization, J. J., E. B. and V. J.; methodology, J. J., and E. B.; formal analysis, J. J., M. P., and N. K. H.; investigation; data curation, J. J.; writing-original draft preparation, J. J.; writing-review and editing E. B., M. P., V. J., and N. K. H.; visualization, J. J., E. B., and N. K. H.; supervision, V. J. All authors have read and approved the final manuscript.

\section{References}

Afonso, O. (2016). R\&D intensity, economic growth and firm-size growth: theory and practice. Applied Economics, 48(32), 29732993. [Google Scholar] [CrossRef

Bekesiene, S. (2015). Duomenu analizes SPSS pagrindai: mokomoji knyga. Vilnius: Generolo Jono Zemaicio Lietuvos karo akademija. [Google Scholar]

Bilan, S., Mishchuk, H., Samoliuk, N., \& Ostasz, G. (2020). Effectiveness of social dialogue in the system of sustainable economic development factors. In Proceedings of the 34th International Business Information Management Association Conference, IBIMA (pp. 13303-13313). [Google Scholar]

Bite, P., Szombathelyi, M. K., \& Vasa, L. (2020). The concept of labour migration from the perspective of Central and Eastern Europe. Economics \& Sociology, 13(1), 197-216. [Google Scholar]

Cangia, F. (2019). "Switzerland Doesn't Want Me"-Work, Precarity and Emotions for Mobile Professionals' Partners. Migration Letters, 16(2), 207-217. [Google Scholar] $561 \mathrm{p}$.

Cekanavicius, V., \& Murauskas, G. (2014). Taikomoji regresine analize socialiniuose tyrimuose, Vilniaus universiteto leidykla,

Chiacchio, F., Petropoulos, G., \& Pichler, D. (2018). The impact of industrial robots on EU employment and wages: A local labour market approach. Bruegel Working Paper, 1(2), 1-33. [Google Scholar]

Chinoracký, R., \& Corejova, T. (2019). Impact of digital technologies on labor market and the transport sector. Transportation research procedia, 40, 994-1001. [Google Scholar] [CrossRef]

Dachs, B. (2017). The impact of new technologies on the labour market and the social economy (No. 90519). University Library of Munich, Germany. [Google Scholar]

De Groen, W. P., \& Maselli, I. (2016). The Impact of the Collaborative Economy on the Labour Market (No. 11625). Centre for European Policy Studies. [Google Scholar]

Donate, M. J., \& Guadamillas, F. (2011). Organizational factors to support knowledge management and innovation. Journal of Knowledge Management, 15(6), 890-914. [Google Scholar] [CrossRef]

Dudu, S. (2021). Effects of Migration Experience on Labour Income in Turkey. Migration Letters, 18(5), 591-600. [Google Scholar]

Fedaraviciute, K. (2008). Moksliniu tyrimy ir eksperimentines pletros efektyvumas ir itaka ekonomikos raidai Europos Sajungos salyse (Doctoral dissertation, Vytautas Magnus University). [Google Scholar]

Gataulinas, A. (2015). Dirbanciuju skurdas Lietuvoje ES kontekste: socialines, ekonomines ir demografines priezastys. Lietuvos socialine raida: Uzimtumo politikos ir socialines pagalbos itaka socialinei stratifikacijai, 75-87. [Google Scholar]

Gedviliene, G., \& Kankeviciene, L. (2014). Informacines visuomenes technologijos ir ju kaita svietimo sistemoje. Versus aureus. [Google Scholar]

Gervyte, A. (2009). Lietuvos darbo rinka. Mikroekonomine analyze (Doctoral dissertation, Mykolas Romeris University). [Google Scholar]

Gulbiniene, N., Jankauskiene, A., \& Sileikaite, G. (2011). Darbo rinkos pletros galimybes kaimo vietovese. Ekonomika ir vadyba: aktualijos ir perspektyvos, (4), 102-112. [Google Scholar] 
J., Jazdauskaite, M., Privarova, E., Baranskaite, V., Juscius, N., Kelemen-Henyel. Evaluation of the Impact of Science and Technology on the Labour Market

Karacsony, P., Izsak, T., \& Vasa, L. (2020). Attitudes of Z generation to job searching through social media. Economics \& Sociology, 13(4), 227-240. [Google Scholar]

Karacsony, P., Vasa, L., Bilan, Y., \& Liptak, K. (2021). Hungarian experiences of the transition from traditional work to telework. Transformations in business \& economics= Verslo in ekonomikos transformacijos. Brno, Kaunas, Riga, Vilnius: Vilniaus universitetas, 2021, vol. 20, no. 3. [Google Scholar]

Kvedariene, A., \& Svediene, L. (2016). Aukstuju technologiju sektoriaus pletra: viesosios paramos sistemos. Viesasis administravimas $=$ Public administration, 3(51), 4. [Google Scholar]

Martinez, W. (2018). How science and technology developments impact employment and education. Proceedings of the National Academy of Sciences, 115(50), 12624-12629. [Google Scholar] [CrossRef

Mićić, L. (2017). Digital transformation and its influence on GDP. Economics, 5(2), 135-147. [Google Scholar] [CrossRef]

Mishchuk, H., Bilan, S., Yurchyk, H. \& Sułkowska, J. (2020). Social Protection of Employees as A Tool of Social Responsibility and Increase of Business Efficiency Proceedings of the 35th International Business Information Management Association (IBIMA), ISBN: 978-0-9998551-4-0, 1-12 April 2020, Seville, Spain, p. 9459-9469

Paliunaite, E. (2011). Nedarbas ir jo atsiradimo priezastys. Vilnius: Mykolo Romerio universitetas. [Google Scholar]

Pocius, A., \& Neverauskiene, L. O. (2015). Tiksliniu grupiu integracijos i darbo rinka galimybiu vertinimas. Lietuvos socialine raida, Uzimtumo politikos ir socialines pagalbos itaka socialinei stratifikacijai, 38-60. [Google Scholar]

Privara, A., Rievajova, E., \& Barbulescu, A. (2020). Attracting High Skilled Individuals in the EU: The Finnish Experience. Migration Letters, 17(2), 369-377. [Google Scholar]

Raisiene, A. G., Rapuano, V., Döry, T., \& Varkuleviciute, K. (2021). Does telework work? Gauging challenges of telecommuting to adapt to a "new normal". Human Technology, 17(2), 126-144. [Google Scholar]

Rechnitzer, J., Berkes, J., \& Filep, B. (2019). The most important city development initiatives of Hungary. Regional Statistics, 9(2), 20-44. Google Scholar[]

Simanaviciene, A., \& Uzkuryte, L. (2009). Pokyciai darbo rinkoje ekonominio nuosmukio metu: Lietuvos atvejis. In Ekonomika ir vadyba (No. 14, pp. 940-946). [Google Scholar]

Supa, M. (2018). Kas yra naujosios technologijos? Apibrezimo ir technologinio turinio problematika ekspertiniuose dokumentuose ir korporatyvineje komunikacijoje. Informacijos mokslai, (83), 101-120. [Google Scholar]

Tomaseviciene, O., \& Staroselskaja, J. (2018). Lietuvos darbo rinkos pokyciai 2008-2016 metais. In Socialiniu moks/4 studijos (No. 10 (2), pp. 322-340). [Google Scholar]

Upadhyay, V. (2015). Can capitalism survive high degree of automation? A comparison with Thomas Piketty's argument. A Comparison with Thomas Piketty's Argument (February 2, 2015). [Google Scholar]

West, D. M. (2015). What happens if robots take the jobs? The impact of emerging technologies on employment and public policy. Centre for Technology Innovation at Brookings, Washington DC. [Google Scholar]

Zhang, F., Wang, Y., \& Liu, W. (2020). Science and technology resource allocation, spatial association, and regional innovation. Sustainability, 12(2), 694. [Google Scholar] [CrossRef]

Йоруне Яздаускайте, Клайпедський університет, Литва

Магдалена Приварова, професор, Економічний університет в Братиславі, Словаччина

Едіта Баранскайте, Dr.Sc., Клайпедський університет, Литва

Вітовт Юскій, Dr.Sc., профессор, Клайпедський університет, Литва

Ніколетта Келемен-Геніель, Угорський університет сільського господарства та природничих наук, Угорщина

Оцінювання впливу розвитку науки та техніки на ринок прац

Авторами наголошено, що інновації, наукові дослідження та нові технології проникають у всі сфери повсякденного життя суспільства, сприяють підвищенню якості життя населення, економічному зростанню країни та її конкурентоспроможності. Поширення робототехніки, штучного інтелекту, автоматичних алгоритмів, 3D друку та програмного забезпечення полегшують виконання поставлених завдань. Своєю чергою відбувається оцифрування інформації. Авторами зазначено, що кожна зі складових рівня розвитку науки та технологій (наукові дослідження та експериментальні розробки, соціальні інновації, високі технології, кадровий потенціал) мають відповідний вплив на економічний розвиток країни. У статті відмічено, що окрім позитивних ефектів розвиток науки і техніки обумовлює появу макроекономічних конфрліктів, зокрема збереження балансу між рівнями зайнятості та безробіття. 3 огляду на це у статті проаналізовано вплив розвитку науки й техніки на ринок праці в Литовській республіці. Інноваційні наукові дослідження та технологічні розробки провокують появу широкомасштабного технологічного безробіття через автоматизацію робочих місць. 3 іншої сторони, інноваційні технології можуть спричинити появу нових підприємств та галузей, а також нових робочих місць та професій. Таким чином, впровадження наукових технологій змінює характер праці, формує попит на висококваліфікованих спеціалістів та нов компетенції. Систематизація наукових напрацювань засвідчила доцільність подальшого дослідження емпіричного обгрунтування впливу розвитку науки та технологій на ринок праці. Для перевірки висунутих гіпотез дослідження авторами використано інструментарій кореляційно-регресійного аналізу та ANOVA-тестування. За результатами кореляційного та регресійного аналізів встановлено, що розвиток науки та технологій сприяють зростанню рівня зайнятості та обсягів місячної заробітної плати населення Литовської республіки, а також мають позитивний вплив на рівень безробіття в країні.

Ключові слова: наука, технології, економічний вплив, технологічний вплив, ринок праці. 